\title{
Distribution of mass transfer over a 0.5-m-tall hydrogen-evolving electrode*
}

\author{
H. F. M. GIJSBERS, L. J. J. JANSSEN \\ Eindhoven University of Technology, Faculty of Chemical Technology, PO Box 513, 5600 MB Eindhoven, \\ The Netherlands
}

Received 30 May 1988; revised 28 November 1988

In general, technical vertical electrolysers for the production of chlorine, hydrogen and oxygen are high and have a short cathode-anode distance. Up to the present, few results on mass transfer to gas-evolving electrodes in these industrial cells have been published. The mass transfer experiments were carried out in a divided cell for a vertical hydrogen-evolving platinum electrode in a solution containing $1 \mathrm{M} \mathrm{KOH}, 0.1 \mathrm{M} \mathrm{KCN}$ and $0.008 \mathrm{M} \mathrm{AgCN}$, where the $\operatorname{Ag}(\mathrm{CN})_{2}^{-}$complex ion was used as the indicator ion. The platinum electrode was divided into 20 segments, each with a height of $24 \mathrm{~mm}$ and a width of $20 \mathrm{~mm}$. Subsequent segments were separated by a $1-\mathrm{mm}$-thick Perspex layer. The height of the platinum electrode was $0.50 \mathrm{~m}$. It has been found that the $\mathrm{Ag} / \mathrm{Ag}(\mathrm{CN})_{2}^{-}$redox couple in an alkaline cyanide solution is very useful in determining mass transfer to a hydrogen-evolving electrode. When no hydrogen bubbles are formed at the working electrode, the mass transfer coefficient decreases at a decreasing rate as the distance from the leading edge of the working electrode increases. For a hydrogen-evolving electrode, however, it has been found that the mass transfer coefficient to the topmost $0.40 \mathrm{~m}$ of the working electrode is practically constant. For the entrance part of the working electrode, about $0.10 \mathrm{~m}$ in length, the dependence of the mass transfer coefficient on the distance to the leading edge of the electrode is complicated. The mass transfer coefficient and the mass transfer enhancement factor for the topmost $0.40 \mathrm{~m}$ of the hydrogen-evolving working electrode are given by complex correlations as a function of the current density required for hydrogen evolution and of the flow rate of solution. The effect of viscosity increase of the solution, caused by addition of a polymer, has been investigated. It has been found that the mass transfer coefficient decreases with increasing viscosity of solution in both cases, namely with and without gas bubble evolution, and that the mass transfer enhancement factor is independent of the viscosity of solution.

\section{Nomenclature}

$a_{1} \quad$ proportionality factor

$A_{\mathrm{c}} \quad$ surface area of electrode $\left(\mathrm{m}^{2}\right)$

$A_{\mathrm{e}, n} \quad A_{\mathrm{e}}$ of segment $n\left(\mathrm{~m}^{2}\right)$

$A_{\text {wm }} \quad$ cross-section of space between working electrode and membrane $\left(\mathrm{m}^{2}\right)$

$c_{\mathrm{b}}$ concentration of $\mathrm{Ag}(\mathrm{CN})_{2}^{-}$in bulk of solution $\left(\mathrm{mol} \mathrm{m}^{-3}\right)$

D. diffusion coefficient $\left(\mathrm{m}^{2} \mathrm{~s}^{-1}\right)$

$D_{\text {Agcy }} \quad D$ for $\mathrm{Ag}(\mathrm{CN})_{2}^{-}\left(\mathrm{m}^{2} \mathrm{~s}^{-1}\right)$

$E$ electrode potential vs $\mathrm{Hg} / \mathrm{HgO} / 1 \mathrm{M} \mathrm{KOH}$ reference electrode (V)

$f$ frequency of rotating electrode $\left(\mathrm{s}^{-1}\right)$

$F \quad$ Faraday constant $=96487\left(\mathrm{C} \mathrm{mol}^{-1}\right)$

$i \quad$ electric current density $\left(\mathrm{kA} \mathrm{m}^{-2}\right)$

$i_{\mathrm{g}} \quad$ limiting electric current density $\left(\mathrm{kA} \mathrm{m}^{-2}\right)$

$I$ electric current (kA, A)

$I_{\mathrm{o} \rightarrow x} \quad I$ on a part of electrode ranging from its leading edge to a distance $x$ from its leading edge ( $\mathrm{kA}, \mathrm{A})$

$k$ mass transfer coefficient of $\mathrm{Ag}(\mathrm{CN})_{2}^{-}\left(\mathrm{ms}^{-1}\right)$ $k_{\mathrm{e}} \quad k$ obtained by extrapolation of $k / i$ curve to $i=0\left(\mathrm{~m} \mathrm{~s}^{-1}\right)$

$k_{\mathrm{f}} \quad k$ at forced convection and in absence of gas bubble evolution on the electrode $\left(\mathrm{m} \mathrm{s}^{-1}\right)$

$k_{\mathrm{f}, n} \quad k_{\mathrm{f}}$ for segment $n\left(\mathrm{~m} \mathrm{~s}^{-1}\right)$

$k_{n} \quad k$ for segment $n\left(\mathrm{~m} \mathrm{~s}^{-1}\right)$

$k_{\mathrm{u}} \quad k$ for the topmost $0.4 \mathrm{~m}$ of electrode $\left(\mathrm{m} \mathrm{s}^{-1}\right)$

$k_{\mathrm{u}, \mathrm{f}} \quad k_{\mathrm{u}}$ at forced convection and in absence of gas bubble evolution on the electrode $\left(\mathrm{m} \mathrm{s}^{-1}\right)$

$Q \quad$ quantity of charge (C)

$Q_{\text {a }} \quad Q$ used for anodic stripping (C)

$Q_{\mathrm{a}, n} \quad Q_{\mathrm{a}}$ for segment $n(\mathrm{C})$

$Q_{\mathrm{c}} \quad Q$ used during cathodic polarization (C)

$Q_{\mathrm{c}, n} \quad Q_{\mathrm{c}}$ for segment $n(\mathrm{C})$

$S \quad$ slip ratio $\left(S=V_{\mathrm{g}} / V_{\mathrm{s}}\right)$

$t$ time (s)

$t_{\mathrm{c}} \quad t$ for cathodic polarization (s)

$T \quad$ temperature $(\mathrm{K})$

$V_{\mathrm{g}} \quad$ volumetric rate of gas production $\left(\mathrm{m}^{3} \mathrm{~s}^{-1}\right)$

$V_{\mathrm{M}} \quad$ volume of $1 \mathrm{~mol}$ gas; $24.4 \times 10^{-3} \mathrm{~m}^{3}$ at $298 \mathrm{~K}\left(\mathrm{~m}^{3}\right)$

$V_{\mathrm{s}} \quad$ volumetric rate of solution $\left(\mathrm{m}^{3} \mathrm{~s}^{-1}\right)$

* Paper presented at the 2nd International Symposium on Electrolytic Bubbles organized jointly by the Electrochemical Technology Group of the Society of Chemical Industry and the Electrochemistry Group of the Royal Society of Chemistry and held at Imperial College, London, 31st May and 1st June 1988. 


$\begin{array}{ll}v_{\mathrm{g}} & \text { velocity of gas bubbles }\left(\mathrm{m} \mathrm{s}^{-1}\right) \\ v_{\mathrm{s}} & \text { solution flow velocity }\left(\mathrm{m} \mathrm{s}^{-1}\right) \\ v_{\mathrm{s}, \mathrm{o}} & \begin{array}{l}\text { solution flow rate on entrance }\left(\mathrm{m} \mathrm{s}^{-1}\right) \\ x\end{array} \\ & \begin{array}{l}\text { distance from the leading edge of the } \\ \text { working electrode to a certain point on this }\end{array} \\ \beta & \text { electrode (m) } \\ \delta_{\mathrm{f}} & \text { enhancement factor for mass transfer } \\ \eta & \text { viscosity of bubble-free solution (m Poise) }\end{array}$

\section{Subscripts}

a average value
b bulk

\section{Introduction}

In general, tall vertical electrolysers are used industrially to produce gases such as chlorine, hydrogen and oxygen. Moreover, industrial electrolysers usually have a very short cathode-anode distance and often operate under forced convection.

For many electrochemical processes mass transfer in electrolytic cells, in particular to electrodes, must be optimized to operate economically. Up to the present, few data on mass transfer to tall vertical gas-evolving electrodes have been published $[1,2]$. To optimize the height or length of the electrode, and thus the dimensions of electrolytic cells, it is very useful to gain insight into the distribution of the mass transfer coefficient over a tall gas-evolving electrode.

Based on the experimental results of the mass transfer coefficient of an indicator ion for a hydrogen- and an oxygen-evolving vertical electrode with a length from 0.05 to $0.16 \mathrm{~m}$ [2] as well as on the behaviour of chlorine, oxygen and hydrogen bubbles attached to the electrode [3, 4], it is to be expected that the mass transfer coefficient for indicator ions is affected most by the electrode length for a hydrogen-evolving electrode in alkaline solution. To investigate the dependence of the mass transfer coefficient on the electrode length, experiments were carried out on a 0.50 -m-high hydrogen-evolving electrode divided into 20 equal segments in alkaline solution.

\section{Experimental details}

\subsection{Solution circuits, electrolytic cell and electrodes}

The experimental set-up with two separate solution circuits was similar to that described in [5]. The electrolytic cell used was a two-compartment Perspex cell; the compartments were separated by a cation-exchange membrane (Nafion, type 117). The cell was positioned vertically. A horizontal cross-section of the cell and a small part of a vertical cross-section of the cell are shown in Figs 1 and 2, respectively.

Both compartments of the cell were rectangular. Their length, width and depth were $0.80,0.020$ and $0.010 \mathrm{~m}$, respectively. The working electrode was fixed in the middle of the back wall of the working electrode

$\begin{array}{ll}\text { c } & \text { cathode } \\ \text { d } & \begin{array}{l}\text { space between working electrode and } \\ \text { membrane }\end{array} \\ \text { e } & \text { electrode; extrapolated } \\ \text { f } & \text { forced convection } \\ \text { g } & \text { gas; limiting } \\ \mathrm{H} & \text { hydrogen } \\ n & \text { segment number } \\ s & \text { solution } \\ \text { s, o } & \text { solution at the entrance of space between } \\ & \begin{array}{l}\text { working electrode and membrane } \\ \text { u }\end{array} \\ \text { topmost } 0.40 \mathrm{~m} \text { of working electrode } \\ \text { wm } & \begin{array}{l}\text { space between working electrode and } \\ \text { membrane }\end{array}\end{array}$

compartment in such a way that the working electrode and the Perspex parts of the back wall of the working electrode compartment were situated in the same plane. For both compartments the inlet and outlet of the solution were placed in, respectively, the lower and upper part of each compartment. The area of the cross-section of the working electrode compartment was $2.0 \times 10^{-4} \mathrm{~m}^{2}$.

The working electrode was divided into 20 equal segments, $20 \mathrm{~mm}$ in width and $24 \mathrm{~mm}$ in height. The subsequent segments were separated by a $1.0-\mathrm{mm}$ thick Perspex strip. The electrode surface area of each segment was $4.8 \times 10^{-4} \mathrm{~m}^{2}$.

The counter electrode was a 'Venetian-blind' electrode, $0.5 \mathrm{~m}$ in length, $0.020 \mathrm{~m}$ in width and $0.005 \mathrm{~m}$ in depth, also divided into 20 equal segments. The counter electrode was placed in the counter electrode compartment against the membrane and opposite the working electrode.

The solutions in both compartments were pumped upwards by centrifugal pumps (Schmitt, type MP80). The volumetric flow rate of the solution was measured with a calibrated flowmeter (Fischer and Porter tube: 3F-3/8-25-5, Float SS-38, float material: stainless steel, density $8.02 \mathrm{~g} \mathrm{~cm}^{-3}$ ). The solution flow velocity at the entrance to the space between the working electrode and the membrane, indicated by the entrance solution flow velocity or by $v_{s, 0}$, was calculated from the volumetric flow rate of the solution through the working electrode compartment and its cross-section.

The size of the thermostatted reservoir for the working electrode circuit was about $4 \times 10^{-3} \mathrm{~m}^{3}$ and that for the counter electrode circuit about $1.0 \times$

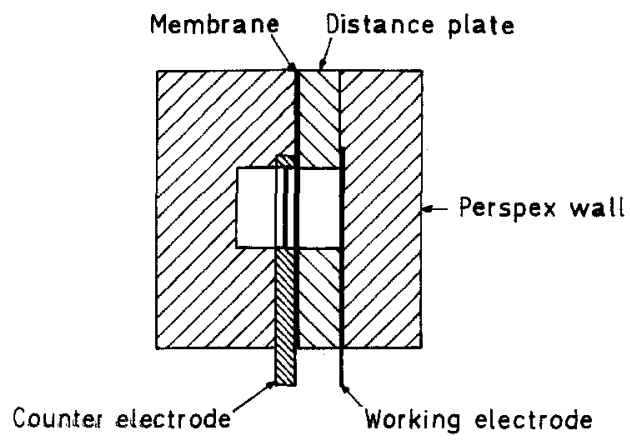

Fig. 1. Scheme of the horizontal cross-section of a flow-through membrane cell. 


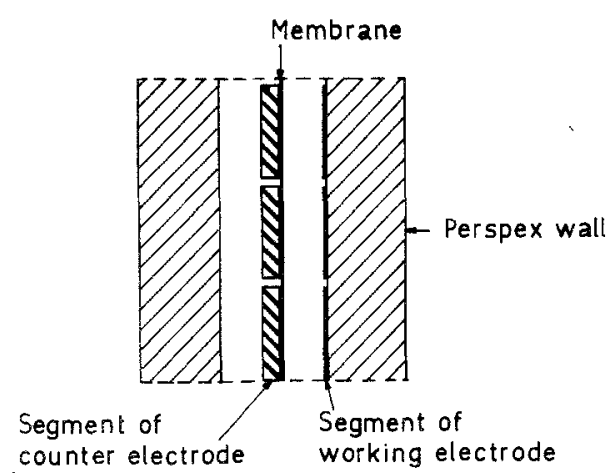

Fig. 2. Scheme of a small part of a vertical cross-section of a flow-through membrane cell.

$10^{-3} \mathrm{~m}^{3}$. The volume of the solution in the working electrode circuit was $5.0 \times 10^{-3} \mathrm{~m}^{3}$, being sufficient to obtain a bubble-free solution at the entrance of the cell.

\subsection{Solution}

To reliably determine the distribution of mass transfer to a hydrogen-evolving electrode, the redox couple $\mathrm{Ag} / \mathrm{Ag}^{+}$in an alkaline cyanide solution has been found very useful. A $1 \mathrm{M} \mathrm{KOH}+0.1 \mathrm{M} \mathrm{KCN}$ solution was used as supporting electrolyte in the working electrode circuit. An accurately known quantity of $\mathrm{AgCN}$, usually corresponding to an $\mathrm{Ag}(\mathrm{CN})_{2}^{-}$concentration of $0.008 \mathrm{M}$, was added to this solution. The concentration of $\mathrm{Ag}(\mathrm{CN})_{2}^{-}$was periodically determined voltammetrically by using a rotating platinum disc electrode. The $\mathrm{KOH} / \mathrm{KCN} / \mathrm{AgCN}$ solution was deoxygenated by passing nitrogen through the solution in the reservoir of the working electrode circuit.

A $30 \mathrm{wt} \%(7 \mathrm{M}) \mathrm{KOH}$ solution was used in the counter electrode circuit. Such a high $\mathrm{KOH}$ concentration was applied to minimize production of heat.

\subsection{Electric measurements}

Silver was deposited on the working electrode during cathodic polarization. Moreover, hydrogen was formed at sufficiently low potentials of the working electrode. During silver deposition, the working electrode was usually polarized galvanostatically. In some experiments, however, potentiostatic polarization of the working electrode was applied. A constant current was delivered by a galvanostat (EMI, type $60 \underline{\mathrm{s}} 45$ ). A reference electrode, an $\mathrm{Hg} / \mathrm{HgO} / 1 \mathrm{M} \mathrm{KOH}$ electrode, was placed in the solution of the working electrode circuit at the outlet of the cell for potentiostatic measurements. A high-power potentiostat (Wenking, type HP72) was used to potentiostatically polarize the whole working electrode during silver deposition, and one or more segments of the working electrode during silver dissolution. The silver deposit formed on a segment of the working electrode during cathodic polarization was dissolved by anodic stripping at a selected potential. The quantity of charge used for anodic dissolution of the silver deposit was measured with an electronic voltage integrator (Wenking, type EVI 80), in parallel with a $20.4-0 \mathrm{hm}$ resistor. This resistor was placed between the counter electrode and the potentiostat. In a few experiments a few segments were polarized potentiostatically and the rest galvanostatically. In these cases, a constant current was delivered by lead-sulphuric acid batteries to prevent shortcircuiting problems.

\subsection{Procedure}

Before starting a series of experiments, the solution of the working electrode circuit was deoxygenated. The nitrogen bubbling was maintained during all the series of experiments.

It has been found that, to obtain reproduceable results, the working electrode has to be activated, in particular, when it has not been used for a long period. This was done by means of cathodic deposition and anodic dissolution of silver. The procedure was carried out simultaneously for all segments and repeated at least three times. All segments were connected to the high power galvanostat in the series of experiments in which hydrogen was evolved on each segment.

For the series of experiments in which hydrogen was not formed on one or two segments, the hydrogenevolving segments were connected to the batteries and the other segments to the potentiostat.

The cathodic polarization of the segments, $t_{\mathrm{c}}$, was timed with a stopwatch. Assuming uniform current distribution over the working electrode, the quantity of charge passed through segment $n$ during cathodic polarization, $Q_{\mathrm{c}, n}=t_{\mathrm{c}} I_{n}$, where $I_{n}$ is the current for segment $n$.

After cathodic polarization of the working electrode, the connections to the galvanostat or the batteries and the potentiostat were broken. Subsequently, each segment was separately connected to the potentiostat. The deposit of silver on each segment was separately dissolved by anodic stripping at a selected potential, usually $0 \mathrm{mV}$ vs the reference electrode. The top segment was stripped first and subsequently the segments downwards. The quantity of charge used for stripping the silver deposit on segment $n, Q_{\mathrm{a}, n, \mathrm{Ag}}$, was proportional to the product volts $\times$ seconds recorded by the integrator. $Q_{\mathrm{a}, n, \mathrm{Ag}}$ was obtained on multiplying resistance $R=20.4 \Omega$, which was parallel to the electronic integrator.

Series of experiments were carried out for currents from 1 to $40 \mathrm{~A}$, flow rates of solution on entrance, $v_{\mathrm{s}, 0}$, from 0.02 to $0.35 \mathrm{~m} \mathrm{~s}^{-1}$ and temperature, $T$, from 298 to $338 \mathrm{~K}$. The time of cathodic polarization of the working electrode was usually $120 \mathrm{~s}$. To increase the reliability of the experimental results, a complete series of experiments, for instance, a series of varying current at constant flow rate of solution and temperature, was carried out in 1 day. The concentration of $\mathrm{Ag}(\mathrm{CN})_{2}^{-}$of the solution of the working electrode compartment was determined before and after each 
series of experiments. It was assumed that the rate of the change in $\operatorname{Ag}(\mathrm{CN})_{2}^{-}$concentration during the series of experiments was constant.

\section{Results}

\subsection{Indicator redox couple}

A redox couple, to be used successfully for mass transfer measurements at hydrogen-evolving electrodes, has to satisfy various criteria, for instance: the components of the redox couple must be stable; the reduction as well as the oxidation step should give only one end product; the reduction rate of the oxidator must be diffusion-limited at potentials where hydrogen evolution also occurs. In alkaline solution, the ferrocyanide-ferricyanide couple is generally used as indicator redox couple. However, this couple is less useful in reliably determining the mass transfer to each segment of a working electrode consisting of a large number of segments. Therefore a new indicator redox couple, namely the $\mathrm{Ag}-\mathrm{Ag}^{+}$couple in alkaline cyanide solution, has been selected. The usefulness of this couple was investigated initially. Typical voltammograms at a rotating platinum disc electrode in an oxygen-free $1 \mathrm{M} \mathrm{KOH}+0.1 \mathrm{M} \mathrm{KCN}+0.02 \mathrm{M}$ $\mathrm{AgCN}$ solution at various rotation frequencies are shown in Fig. 3. Based on a $\mathrm{p} K$ of 21 [7] for the reaction $\mathrm{Ag}\left(\mathrm{CN}_{2}^{-} \rightarrow \mathrm{AgCN}+\mathrm{CN}^{-}\right.$and the solubility product $\left[\mathrm{Ag}^{+}\right]\left[\mathrm{Ag}(\mathrm{CN})_{2}^{-}\right]=10^{-6} \mathrm{~mol}^{2} \mathrm{~m}^{-6}$ [8], it follows that in $\mathrm{CN}$ excess, practically only $\mathrm{Ag}[\mathrm{CN}]_{2}^{-}$is present as an $\mathrm{Ag}$ compound. The voltammograms show reasonable limiting current density plateaux. Plotting the disc current density, $i_{\mathrm{s}, \mathrm{g}}$, at the inflection point in the limiting current density region as a function of the square root of the rotation frequency, $f$, a linear relationship between $i_{\mathrm{s}, \mathrm{g}}$ and $f^{1 / 2}$ was found. Using the Levich equation for a rotating disc electrode and introducing the appropriate values for the various factors, it was calculated that the diffusion coefficient for $\mathrm{Ag}(\mathrm{CN})_{2}^{-}, D_{\mathrm{Ag}(\mathrm{CN})^{-}}$, in $1 \mathrm{M}$ $\mathrm{KOH}+0.1 \mathrm{M} \mathrm{KCN}+0.02 \mathrm{M} \mathrm{AgCN}^{2}$ solution at $298 \mathrm{~K}$ is equal to $8.9 \times 10^{-10} \mathrm{~m}^{2} \mathrm{~s}^{-1}$. This value is lower than that given in [6], namely $14.2 \times$

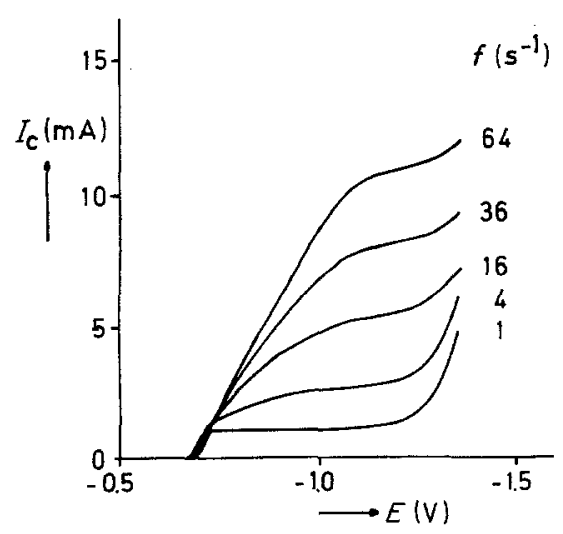

Fig. 3. Voltammograms at a rotating platinum disc in an oxygenfree $1 \mathrm{M} \mathrm{KOH}+0.1 \mathrm{M} \mathrm{KCN}+0.02 \mathrm{M} \mathrm{AgCN}$ solution at $298 \mathrm{~K}$ and various rotation frequencies. The numbers at the curves indicate the rotation frequency in $\mathrm{s}^{-1}$.
$10^{-10} \mathrm{~m}^{2} \mathrm{~s}^{-1}$ in $0.05 \mathrm{M} \mathrm{KNO}_{3}+2.5 \times 10^{-3} \mathrm{M} \mathrm{KBr}$ solution at $298 \mathrm{~K}$.

Similar voltammograms as in Fig. 3 were obtained for $\mathrm{Ag}$ deposition on the 0.5 -m-high working electrode under conditions of forced flow. The limiting current for Ag deposition was attained at a potential of about $-1.05 \mathrm{~V}$.

The effect of the anodic strip potential on the dissolution of $\mathrm{Ag}$ was investigated with a rotating platinum disc electrode. Because of a $100 \%$ current efficiency for $\mathrm{Ag}$ deposition, $\mathrm{Ag}$ was deposited from an oxygen-free $1 \mathrm{M} \mathrm{KOH}+0.8 \mathrm{M} \mathrm{KCN}+0.2 \mathrm{M}$ $\mathrm{AgCN}$ solution at a current equal to half the limiting current. In this case, both the charge used during cathodic deposition of $\mathrm{Ag}, Q_{\mathrm{c}, \mathrm{Ag}}$, and that used during anodic dissolution of $\mathrm{Ag}, Q_{\mathrm{a}, \mathrm{Ag}}$, were determined by a voltage integrator. It was found that the ratio $Q_{\mathrm{a}, \mathrm{Ag}} /$ $Q_{\mathrm{c}, \mathrm{Ag}}$ was 1.00 for anodic stripping potentials from -0.5 to $+0.5 \mathrm{~V}$. The time of anodic stripping decreases strongly with increasing potential and attains a limiting value at about $0 \mathrm{~V}$. The stripping potential of $0 \mathrm{~V}$ was also very useful for the mass transfer experiments in the tall cell and was usually applied.

The dependence of the flow rate of solution on the ratio $Q_{\mathrm{a}, \mathrm{Ag}} / Q_{\mathrm{c}, \mathrm{Ag}}$ was investigated for the working electrode in the tall cell. Silver was deposited at $-1.05 \mathrm{~V}$. The selected time of cathodic polarization depended on the flow rate of solution. The charge $Q_{\mathrm{c}, \mathrm{Ag}}$ varied between 8.8 and $19.4 \mathrm{C}$ for the whole working electrode. It was found that the ratio $Q_{\mathrm{a}, \mathrm{Ag}} / Q_{\mathrm{c}, \mathrm{Ag}}$ was 0.984 , that being independent of the flow rate of solution for the range 0.02 to $0.35 \mathrm{~m} \mathrm{~s}^{-1}$. From this result it follows that Ag particles do not peel off the electrode surface during both the deposition and the dissolution of Ag. A lower ratio was found for the first experiment of a series when the electrode had not been activated. In this case, adhesion of $\mathbf{A g}$ particles to a platinum surface may be rather poor because of the presence of (organic) impurities on the platinum surface.

To study the effect of the flow rate of solution during anodic stripping on the adhesion of $\mathrm{Ag}$ particles formed in the potential range where hydrogen bubbles are also evolved at a high rate, one segment was cathodically polarized at $1 \mathrm{~A}$ for $60 \mathrm{~s}$ at a solution flow rate of $0.02 \mathrm{~m} \mathrm{~s}^{-1}$. After $\mathrm{Ag}$ deposition the flow rate of solution was adjusted to a value between 0.02 and $0.35 \mathrm{~m} \mathrm{~s}^{-1}$ and the $\mathrm{Ag}$ deposit was stripped after $300 \mathrm{~s}$. It was found that $Q_{\mathrm{a} . \mathrm{Ag}}$ was independent of the flow rate of solution during anodic stripping and was equal to $0.767 \mathrm{C}$. Only about $1.2 \%$ of the cathodic charge was used for $\mathrm{Ag}$ deposition, the rest for hydrogen evolution. A rough $\mathrm{Ag}$ deposit on the segment has formed at a high rate of evolution of hydrogen bubbles [7].

It takes some time to attain a steady rate of mass transfer of $\mathrm{Ag}(\mathrm{CN})_{2}^{-}$ions to a hydrogen-evolving electrode, depending on the flow rate of solution. To gain insight into this factor, experiments were carried out at a cathodic current of $10 \mathrm{~A}$ and a flow rate of solution of $0.1 \mathrm{~m} \mathrm{~s}^{-1}$, at various times of cathodic 
polarization, $t_{\mathfrak{c}}$, namely from 10 to $120 \mathrm{~s}$. It was found that the $Q_{\mathrm{a}, \mathrm{Ag}} / t_{\mathrm{c}}$ for the whole working electrode decreased by about $20 \%$ for an increase in $t_{\mathrm{c}}$ from 10 to $20 \mathrm{~s}$. For $t_{\mathrm{c}}>20 \mathrm{~s}$, the ratio $Q_{\mathrm{a}, \mathrm{Ag}} / t_{\mathrm{c}}$ was practically constant.

Based on the above results, it follows that the $\mathrm{Ag}-$ $\mathrm{Ag}^{+}$redox couple in an alkaline cyanide solution is very useful in determining mass transfer to hydrogenevolving electrodes.

\subsection{Calculation of the mass transfer coefficient}

The limiting current density for the reduction of $\mathrm{Ag}(\mathrm{CN})_{2}^{-}$is given by

$$
i_{\mathrm{g}, \mathrm{Ag}}=F k c_{\mathrm{b}}
$$

where

$k=$ mass transfer coefficient for $\mathrm{Ag}(\mathrm{CN})_{2}^{-}$

$c_{\mathrm{b}}=\mathrm{Ag}(\mathrm{CN})_{2}^{-}$concentration in the bulk of solution.

The quantity of $\mathrm{Ag}$ deposited during cathodic polarization was determined by anodic stripping at $0 \mathrm{~V}$ and is equal to $Q_{\mathrm{a}, \mathrm{Ag}} / F$. When the rate of $\mathrm{Ag}$ deposition does not depend on the time of cathodic polarization, $t_{\mathrm{c}}$, and the $\mathrm{Ag}$ deposition is diffusion controlled, it can be shown that the mass transfer coefficient of $\mathrm{Ag}(\mathrm{CN})_{2}$ is

$$
k=\frac{Q_{\mathrm{a}, \mathrm{Ag}}}{A_{\mathrm{e}} t_{\mathrm{c}} \mathcal{c}_{\mathrm{b}}}
$$

Using Equation 2, the mass transfer coefficient $k_{n}$ for segment $n$ was calculated with a specifically designed computer program. The bulk concentration of $\mathrm{Ag}(\mathrm{CN})_{2}^{-}$at mid-segment level $n$ was used to calculate $k_{n}$. The bulk concentration of $\mathrm{Ag}(\mathrm{CN})_{2}^{-}$decreases with increasing distance, $x$, from the leading edge of the working electrode. This distance is called the height in the cell. The decrease in $c_{b}$ is related to the rate of $\mathrm{Ag}$ deposition, the flow rate of solution on entrance to the cell at the level of the leading edge of the working electrode $\left(v_{s, 0}\right)$ the volumetric rate of hydrogen evolution, the slip of hydrogen bubbles in the solution and the cross-section of the working electrode compartment. The decrease in the bulk concentration of $\mathrm{Ag}(\mathrm{CN})_{2}^{-}$was calculated as a function of the distance $x$ assuming: (1) equal distributions of the gas void fraction and $\operatorname{Ag}(\mathrm{CN})_{2}$ concentration over the cross-section of the working electrode compartment;
(2) equal distribution of the current used for hydrogen production over the working electrode; (3) all the hydrogen formed is directly evolved as bubbles; (4) the volumetric rate of hydrogen production is $I_{\mathrm{H}} V_{\mathrm{M}} / 2 F$, where $V_{\mathrm{M}}$ is the volume of $1 \mathrm{~mol}$ gas, namely $24.4 \times 10^{-3} \mathrm{~m}^{3}$ at $298 \mathrm{~K}$; (5) the current used for hydrogen production over a distance $x$ from the leading edge $I_{0 \rightarrow x, \mathrm{H}}=I_{0 \rightarrow x}-I_{0 \rightarrow x, \mathrm{Ag}}$ and; (6) the slip ratio (also called the phase velocity ratio), defined by $S=V_{\mathrm{g}} / V_{\mathrm{s}}[9]$, where $V_{\mathrm{g}}$ is the average gas velocity and $V_{\mathrm{s}}$ the average liquid velocity, for hydrogen bubbles is about 1.5 at $v_{\mathrm{s}}=0.05 \mathrm{~m} \mathrm{~s}^{-1}$ [10].

Evidently, the largest decrease in $\mathrm{Ag}(\mathrm{CN})_{2}^{-}$concentration was calculated for the highest current, $40 \mathrm{~A}$, and the lowest flow rate of solution, $0.02 \mathrm{~m} \mathrm{~s}^{-1}$. In this case the $\operatorname{Ag}(\mathrm{CN})_{2}^{-}$concentration at the top of the working electrode was $9.2 \%$ smaller than that at the bottom of the working electrode. Because of this value for the most extreme conditions used, the assumptions made on the decrease in $\operatorname{Ag}(\mathrm{CN})_{2}^{-}$concentration do not significantly affect the experimental mass transfer coefficient of $\mathrm{Ag}(\mathrm{CN})_{2}^{-}$.

\subsection{Mass transfer in the absence of hydrogen evolution}

A series of experiments at various cathodic potentials showed that $Q_{\mathrm{a}, \mathrm{Ag}}$ was practically constant and that hydrogen bubbles were not formed in the potential range from -900 to $-1150 \mathrm{mV}$.

In Fig. $4, k_{\mathrm{f}, n}$ is plotted vs the segment number, $n$, for the working electrode at various solution flow rates. Before determination of $k_{\mathfrak{\wp}, n}$, the working electrode had been used for mass transfer experiments for four periods, each of about $8 \mathrm{~h}$.

To control the stability of the segmented working electrode, three series of experiments at $-1050 \mathrm{mV}$ and $v_{\mathrm{s}, 0}=0.1 \mathrm{~m} \mathrm{~s}^{-1}$ were spread over a half year period of the experimental work. It was found that the dependence of the mass transfer coefficient, $k_{\mathrm{f}, n}$, in the absence of gas evolution, on segment number $n$, had not changed. The $k_{\mathrm{f}, n} / n$ curve had become less smooth; the fluctuation in $k_{n}$ for subsequent segments had increased because of the change in position of some segments. Moreover, the bright platinum sheets placed in the back wall of the working electrode com-

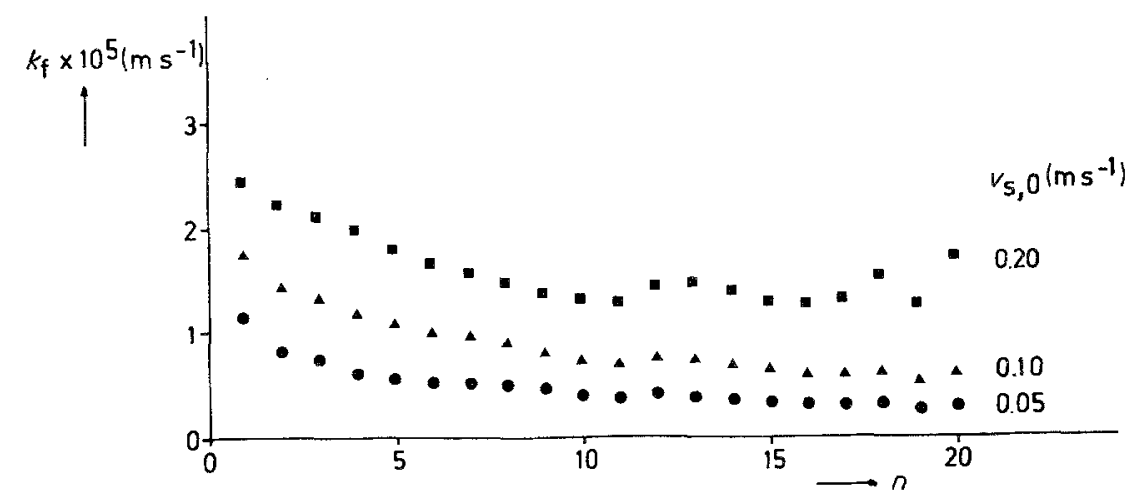

Fig. 4. The mass transfer coefficient in absence of gas evolution for each segment of the segmented electrode at various flow rates of solutions. 


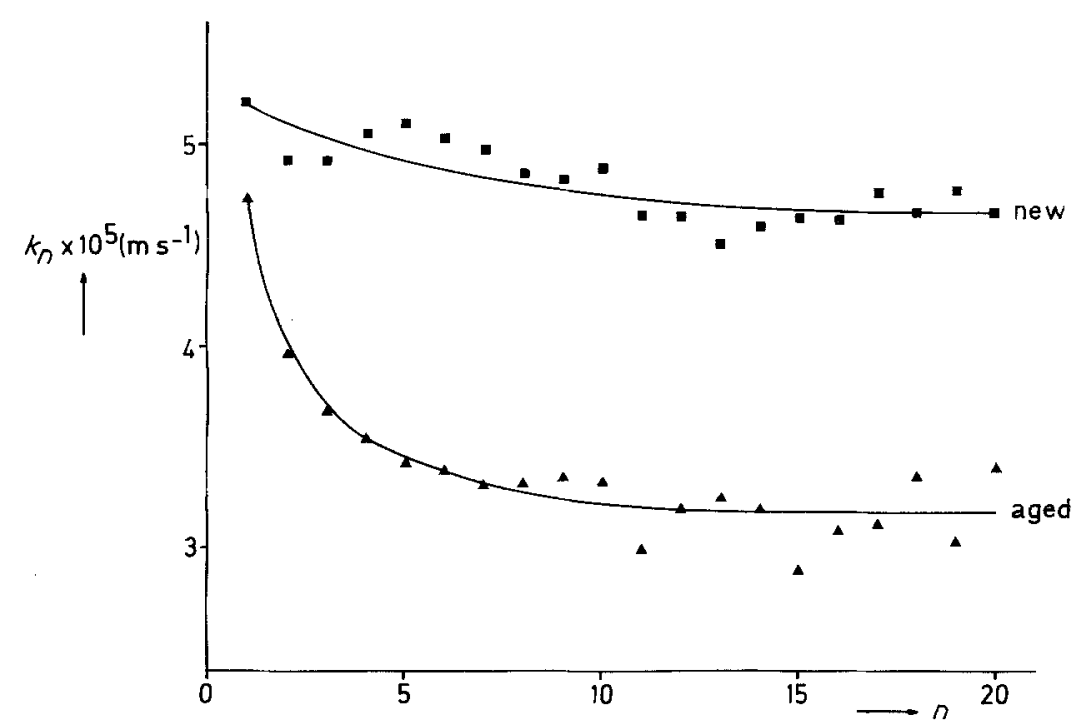

Fig. 5. The mass transfer coefficient for each segment for a new and an aged segmented hydrogen-evolving electrode at $i=1 \mathrm{kAm}^{-2}$ and a flow rate of solution on entrance of $0.1 \mathrm{~m} \mathrm{~s}^{-1}$.

partment had become dull during the period of experimental work.

Plotting $k_{\mathrm{f}, n}$ as a function of $v_{\mathrm{s}, \mathrm{o}}$ on a double logarithmic scale for various segments shows that the slope of the $\log k_{\mathrm{f}, n} / \log v_{\mathrm{s}, 0}$ curve increases at decreasing rate with increasing $v_{s, 0}$ and segment number $n$. The slope for $n=20$ at $v_{\mathrm{s}, 0}=0.2 \mathrm{~m} \mathrm{~s}^{-1}$ is 1.0 .

\subsection{Mass transfer to a hydrogen-evolving electrode}

3.4.1. The whole working electrode. Generally, the series of experiments were carried out at a constant solution flow rate and temperature and subsequently at a current density of $4,3,2,1,0.5,0.3,0.2$ and $0.1 \mathrm{kA} \mathrm{m}^{-2}$. This experimental work was carried out during two separate periods of time; the first series of experiments at three solution flow rates in the first period and those at eight solution flow rates in the second period.

Figure 5 shows typical $k_{n} / n$ curves at $v_{\mathrm{s}, \mathrm{o}}=$ $0.1 \mathrm{~m} \mathrm{~s}^{-1}$ and $i=2 \mathrm{kA} \mathrm{m}^{-2}$ for both periods. Taking into consideration the fluctuation in $k_{n}$ from both curves it follows that $k_{n}$ is practically constant for $n>4$ or for the topmost $0.40 \mathrm{~m}$ of the working electrode. The average value of $k_{n}$ for this part of the electrode is indicated by $k_{\mathrm{u}, \mathrm{a}}$. It has been found that $k_{\mathrm{u}, \mathrm{a}}$ is practically constant during the first as well as the second period. Before starting the second period, the platinum working electrode was kept constant with an alkaline cyanide solution for 2 months. The nature of the platinum working electrode had probably changed in this 2-month period. The working electrodes in the first and second periods of experimental work are indicated by the new and the aged working electrode, respectively. The difference in the nature of the electrode surface strongly affects the shape of the $k_{n} / n$ curve at $n<5$ (Fig. 5). Moreover, the reproducibility of the $k_{n} / n$ curve at $n<5$ is rather poor.

Figures 6 and 7 show $k_{n} / n$ curves for the aged working electrode at $v_{\mathrm{s}, \mathrm{o}}=0.05$ and $0.25 \mathrm{~m} \mathrm{~s}^{-1}$, respectively, and at various rates of hydrogen evolution. The effect of the flow rate of solution $v_{\mathrm{s}, \mathrm{o}}$ on the $k_{n} / n$ curve at a constant rate of hydrogen evolution, namely $2 \mathrm{kA} \mathrm{m}^{-2}$, is shown in Fig. 8. From these figures it also follows that $k_{n}$ is practically constant for $n>4$. To illustrate the increase in the void fraction, $f_{\mathrm{g}}$, with increasing height in the cell and its possible effect on the mass transfer, $f_{\mathrm{g}}$ and $k$ are plotted in Fig. 9 as a function of segment number or of increasing height in the cell under extreme experimental con-

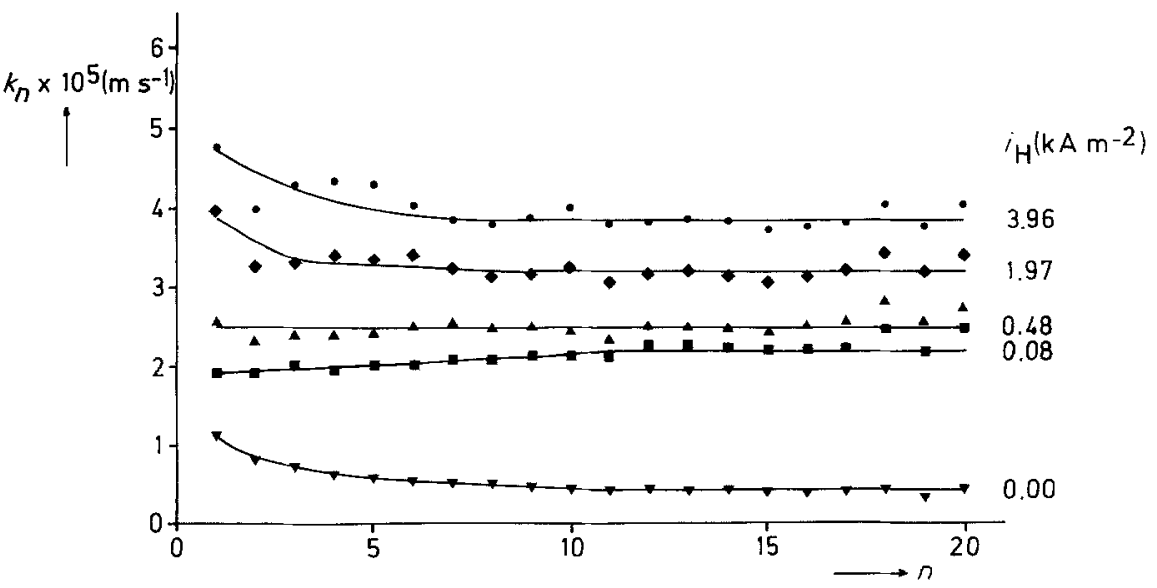

Fig. 6. The mass transfer coefficient for each segment for an aged segmented electrode at a flow rate of solution on entrance of $0.05 \mathrm{~m} \mathrm{~s}^{-1}$ at various rates of hydrogen evolution. 


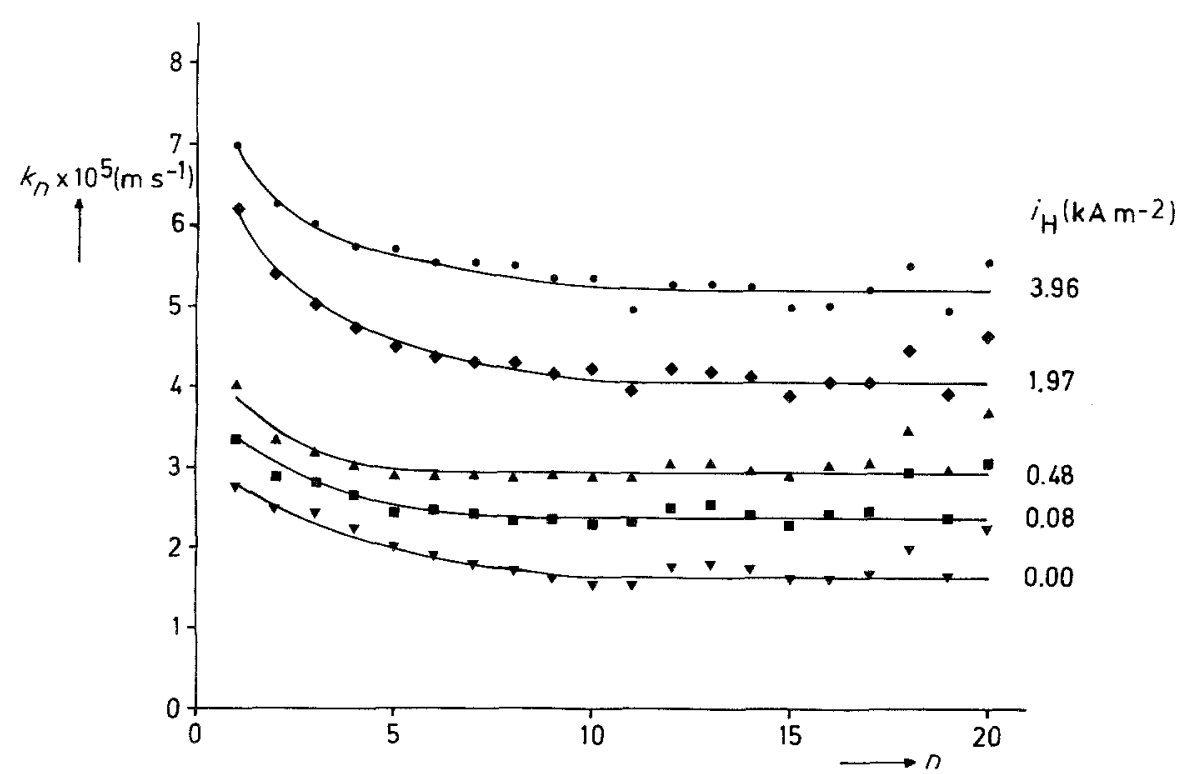

Fig. 7. Mass transfer coefficient for each segment for an aged segmented electrode at a flow rate of solution on entrance of $0.25 \mathrm{~m} \mathrm{~s}^{-1}$ and at various rates of hydrogen evolution.

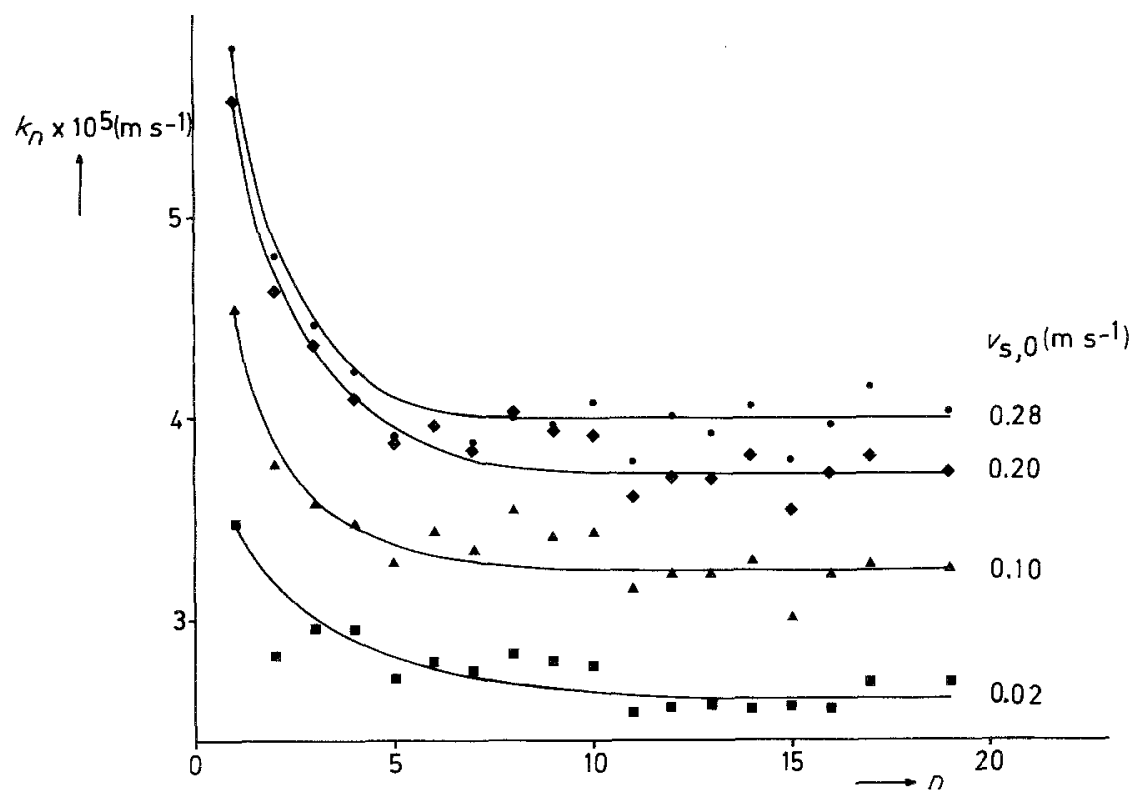

Fig. 8. Mass transfer coefficient for each segment for an aged segmented electrode at a rate of hydrogen evolution of $1 \mathrm{kA} \mathrm{m}^{-2}$ and at various flow rates of solution on entrance.

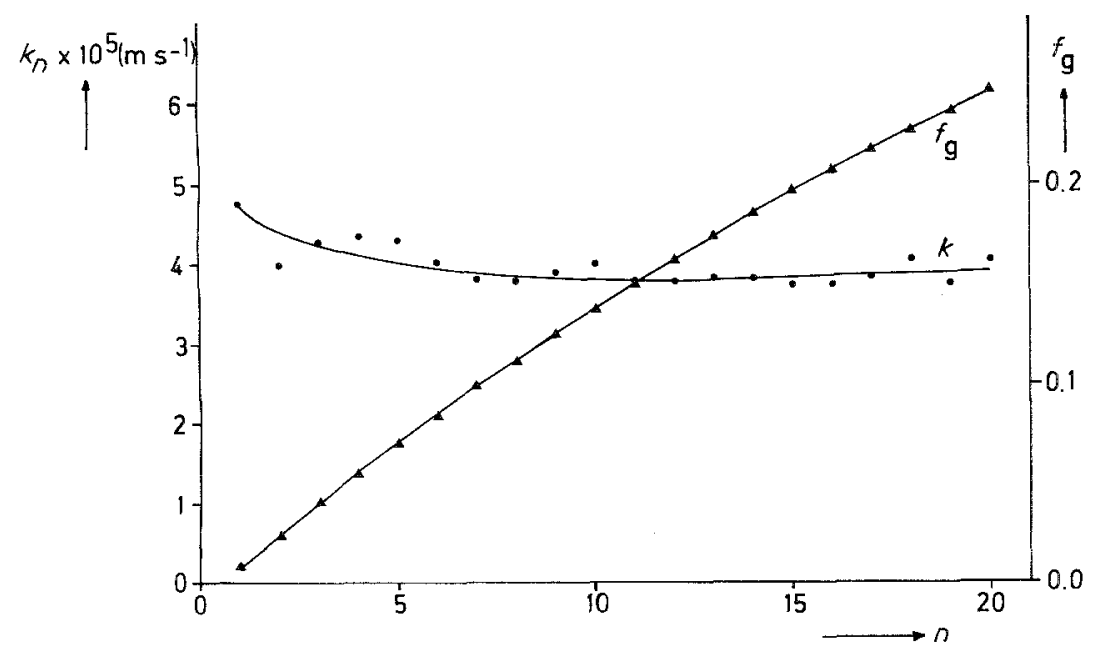

Fig. 9. Mass transfer coefficient for each segment and the gas void fraction in the segmented electrode compartment at the level of the middle of each segment for an aged segmented electrode at a rate of hydrogen evolution of $2 \mathrm{kA} \mathrm{m}^{-2}$ and at a flow rate of solution on entrance of $0.05 \mathrm{~m} \mathrm{~s}^{-1}$. 


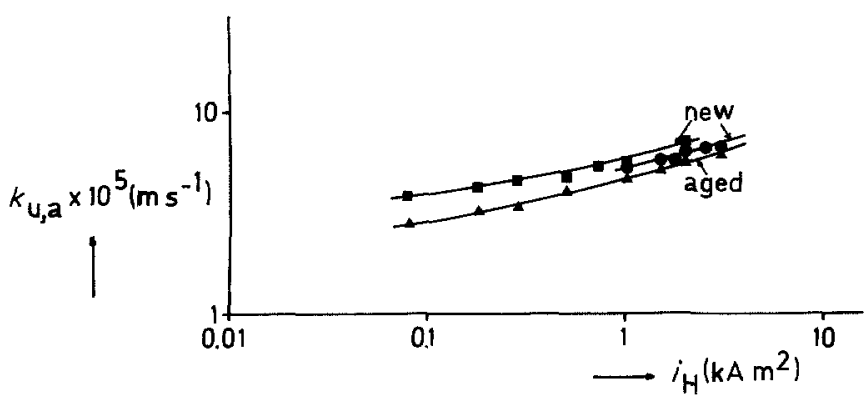

Fig. 10. Average mass transfer coefficient for the topmost $0.4 \mathrm{~m}$ of an electrode plotted as a function of current density $i_{H}$ on a double logarithmic scale for a new and an aged electrode at a flow rate of solution on entrance of $0.1 \mathrm{~ms}^{-1}$. Two series of experiments are shown for a new electrode. ditions, namely the highest current density, $4 \mathrm{kA} \mathrm{m}^{-2}$, and a low solution flow rate, $v_{\mathrm{s}, 0}$, of $0.05 \mathrm{~m} \mathrm{~s}^{-1}$. As mentioned in Section 3.2, it is assumed that the slip ratio $\dot{S}=1.5[10]$. When the velocity of bubbles is equal to that of the liquid $(S=1)$, it can be calculated that $f_{\mathrm{g}}$ at the top of the working electrode at $4 \mathrm{kA} \mathrm{m}^{-2}$ and $v_{\mathrm{s}, 0}=0.05 \mathrm{~m} \mathrm{~s}^{-1}$ is equal to 0.34 .

\subsubsection{The topmost $0.4 \mathrm{~m}$ of a working electrode.}

3.4.2.1. Rate of hydrogen evolution and rate of solution flow. The effect of the current density, $i_{\mathrm{H}}$, on $k_{\mathrm{u}, \mathrm{a}}$ is given in Fig. 10 for both the new and the aged electrode at $v_{\mathrm{s}, 0}=0.1 \mathrm{~m} \mathrm{~s}^{-1}$. The average mass transfer coefficient for the $0.40 \mathrm{~m}$ upper part of the working electrode in the absence of gas evolution, $k_{\mathrm{f}, \mathrm{a}}=$ $7.3 \times 10^{-6} \mathrm{~m} \mathrm{~s}^{-1}$ for the new as well as the aged electrode. Figure 8 shows that both curves are parallel. This result was also obtained at $v_{s, o}=0.02$ and $0.35 \mathrm{~m} \mathrm{~s}^{-1}$. Hence the slope of the $\log k_{\mathrm{u}, \mathrm{a}} / \log i_{\mathrm{H}}$ curve does not depend on the nature of the electrode surface. It was found that the slope of the $\log k_{\mathrm{u}, \mathrm{a}} / \log v_{\mathrm{s}, \mathrm{o}}$ is also independent of the nature of the electrode surface.

Figure 11 shows $k_{\mathrm{u}, \mathrm{a}}$ as a function of $i_{\mathrm{H}}$ on a doublelogarithmic scale for the aged electrode at various solution flow rates on entrance. From this figure it follows that the slope of the $\log k_{\mathrm{u}, \mathrm{a}} / \log i_{\mathrm{H}}$ curve does not depend on $v_{\mathrm{s}, \mathrm{o}}$. It can be shown that the curve of Fig. 11 can be represented by $k_{\mathrm{u}, \mathrm{a}}=n_{1}+n_{2} i^{0.38}$, where $n_{1}$ and $n_{2}$ are factors depending on $v_{\mathrm{s}, \mathrm{o}}$.

The effect of the flow rate of solution on entrance on $k_{\mathrm{u}, \mathrm{a}}$ has been determined by a special series of experiments. A set of two experiments, one at a working electrode potential of $-1050 \mathrm{mV}$ and one at a working electrode polarization with $2 \mathrm{kA} \mathrm{m}^{-2}$, were subsequently carried out for increasing $v_{\mathrm{s}, \mathrm{o}}$ in 1 day.

In Fig. $12 k_{\mathrm{u}, \mathrm{a}}$ at $i_{\mathrm{H}}=2 \mathrm{kA} \mathrm{m}^{-2}$ is plotted as a function of $v_{\mathrm{s}, \mathrm{o}}$. To illustrate the effect of the flow rate of solution in the absence of hydrogen evolution, the mass transfer coefficient, $k_{\mathrm{f}}$, for segment 15 is also given in Fig. 12. It was found that $k_{\mathrm{f}}$ decreased at a decreasing rate with increasing height in the cell for the topmost $0.40 \mathrm{~m}$ of the working electrode also. In spite of that, $k_{\mathrm{f}}$ for segment $15, k_{\mathrm{f}, 15}$, reasonably indicates the average $k_{\mathrm{f}}$ for that part of the working electrode.

From Fig. 12 it can be shown that

$$
\begin{gathered}
k_{\mathrm{u}, \mathrm{a}}=\left(2.6+3.4 v_{\mathrm{s}, \mathrm{o}}^{0.71}\right) \times 10^{-5} \mathrm{~m} \mathrm{~s}^{-1} \\
\text { at } i_{\mathrm{H}}=2 \mathrm{kA} \mathrm{m}^{-2}
\end{gathered}
$$

where $v_{\mathrm{s}, \mathrm{o}}$ is given in $\mathrm{m} \mathrm{s}^{-1}$.

Extrapolation of the $\log k_{\mathrm{u}, \mathrm{a}} / \log i_{\mathrm{H}}$ function to $\log$ $i_{\mathrm{H}}=-\infty$ gives $\log k_{\mathrm{u}, \mathrm{a}, \mathrm{e}}$ (Fig. 11). Plotting $\log (\log$ $\left.k_{\mathrm{u}, \mathrm{a}}-\log k_{\mathrm{u}, \mathrm{a}, \mathrm{e}}\right)$ as a function of $\log i_{\mathrm{H}}$ gives a straight line with slope 0.38 and $\log \left(\log k_{\mathrm{u}, \mathrm{a}}-\log k_{\mathrm{u}, \mathrm{a}, \mathrm{e}}\right)$ at $i_{\mathrm{H}}=1 \mathrm{kA} \mathrm{m}^{-2}$ is equal to -0.62 . From these results and using the relation deduced from Fig. 12, it follows that

$$
k_{\mathrm{u}, \mathrm{a}}=\left[1.3+1.7 v_{\mathrm{s}, \mathrm{a}}^{0.71}\right] 10^{\left[-5+0.24 i_{\mathrm{H}}^{0.38}\right]} \mathrm{m} \mathrm{s}^{-1}
$$

where $v_{\mathrm{s}, \mathrm{o}}$ and $i_{\mathrm{H}}$ are given in $\mathrm{ms}^{-1}$ and $\mathrm{kA} \mathrm{m}^{-2}$, respectively.

From Fig. 12 it follows that $k_{\mathrm{f}, 15}=(0.15+$ $\left.6.25 v_{\mathrm{s}, \mathrm{o}}\right) \times 10^{-5} \mathrm{~m} \mathrm{~s}^{-1}$ where $v_{\mathrm{s}, \mathrm{o}}$ is given in $\mathrm{m} \mathrm{s}^{-1}$. $k_{\mathrm{f}, 15}$ is approximately equal to $k_{\mathrm{u}, \mathrm{f}, \mathrm{a}}$. Introducing the enhancement factor $\beta=\left(k_{a} / k_{f, a}\right)-1$, it can be shown that the average enhancement factor for the topmost $0.40 \mathrm{~m}$ of the working electrode is

$$
\beta_{\mathrm{a}}=-1+\left[\frac{1.3+1.7 v_{\mathrm{s}, \mathrm{o}}^{0.71}}{0.15+6.25 v_{\mathrm{s}, \mathrm{o}}}\right] 10^{+0.24 i_{\mathrm{H}}^{0.38}}
$$

where $v_{\mathrm{s}, \mathrm{o}}$ and $i_{\mathrm{H}}$ are given in $\mathrm{ms}^{-1}$ and $\mathrm{kAm}^{-2}$, respectively.

3.4.2.2. Effect of temperature. The effect of temperature on the mass transfer to the segmented working electrode was determined for the new as well as the aged electrode. A series of experiments was carried out for increasing temperature at a constant current and flow rate of solution; for some temperatures this

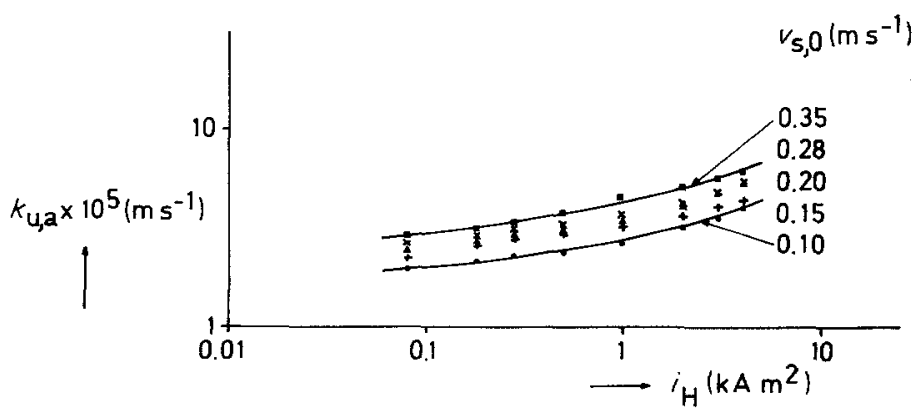

Fig. 11. Average mass transfer coefficient for the topmost $0.4 \mathrm{~m}$ of an electrode plotted as a function of current density $i_{\mathrm{H}}$ on a double logarithmic scale for an aged electrode at various solution flow rates on entrance. 


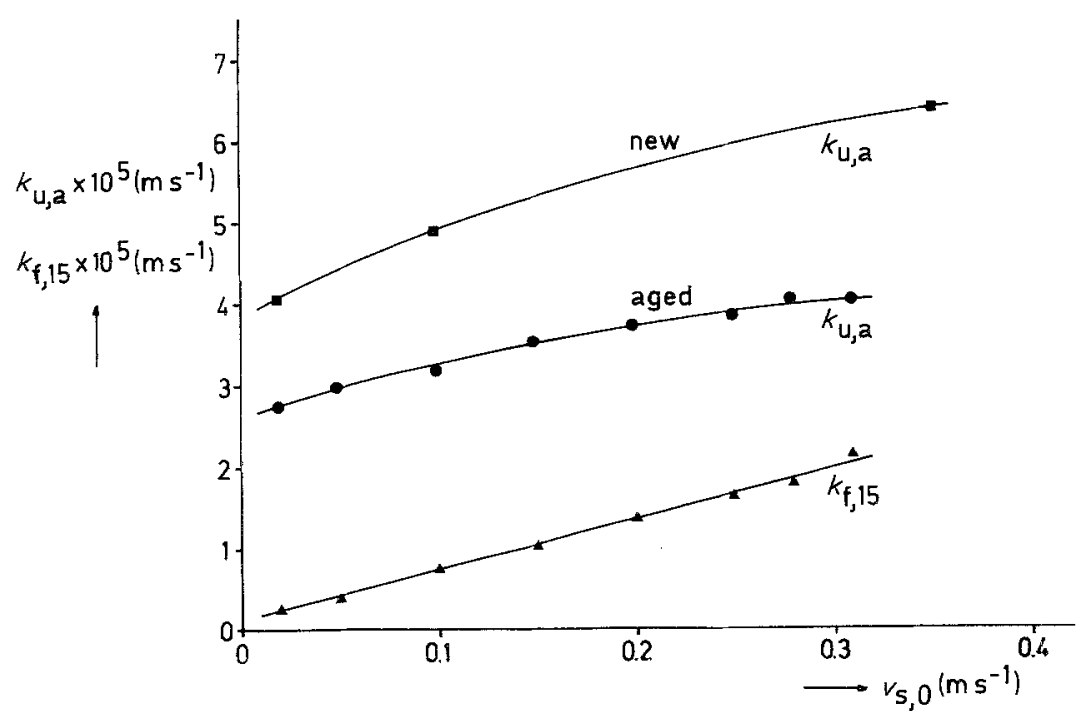

Fig. 12. Average mass transfer coefficient for the topmost $0.4 \mathrm{~m}$ of an electrode plotted as a function of fiow rate of solution on entrance for an aged electrode at $i_{\mathrm{H}}=1 \mathrm{kA} \mathrm{m}^{-2}$. Moreover, the mass transfer coefficient for segment 15 , in the absence of gas evolution, is given as a function of flow rate of solution on entrance.

was also done at various currents and various solution flow rates.

It was found that the mass transfer coefficient was practically independent of the segment number for the topmost $0.4 \mathrm{~m}$ of the working electrode at temperatures from 294 to $338 \mathrm{~K}$. Plotting $k_{\mathrm{u}, \mathrm{a}}$ as a function of $i_{\mathrm{H}}$ on a double logarithmic scale for a series of experiments at solution flow rates of 0.05 and $0.28 \mathrm{~m} \mathrm{~s}^{-1}$ gave parallel curves.

Figure 13 shows $k_{\mathrm{u}, \mathrm{a}}$ as a function of $T^{-1}$ for the new working electrode at $i=1.5 \mathrm{kA} \mathrm{m}^{-2}$ and at $v_{\mathrm{s}, \mathrm{o}}=$ $0.1 \mathrm{~m} \mathrm{~s}^{-1}$. The relation between $\log k_{\mathrm{u}, \mathrm{a}}$ and $T^{-1}$ is linear; the slope of the straight line is $1.1 \times 10^{3} \mathrm{~K}$. Practically the same slope was found for the aged electrode. From experimental mass transfer coefficients in the absence of hydrogen evolution at two temperatures it follows that for the topmost $0.4 \mathrm{~m}$ of the electrode the slope of the $\log k_{\mathrm{f}} / T^{-1}$ curve is $0.2 \times 10^{3} \mathrm{~K}$.

3.4.2.3. Effect of viscosity. Carboxymethylcellulose sodium salt (CMC) was added to $1 \mathrm{M} \mathrm{KOH}+0.1 \mathrm{M}$ $\mathrm{KCN}+0.0085 \mathrm{M} \mathrm{AgCN}$ solution, in order to vary the viscosity following the work of Cavatorta and Böhm [11]. Based on their results, it is likely that the density of the $\mathrm{KOH}-\mathrm{KCN}-\mathrm{AgCN}$ solution is practically unaffected by the addition of a small quantity of CMC up to $60 \mathrm{~g} \mathrm{CMC} \mathrm{m}^{-3}$; the viscosity, however, changes a great deal. The viscosity was measured with a Ubbelhode-type viscometer. The results of these measurements are given in Fig. 14. The increase in viscosity is less than that found by Cavatorta et al. [11], probably due to differences in the molecular weight of the CMC used. The diffusion coefficient of $\mathrm{Ag}(\mathrm{CN})_{2}^{-}$was determined from voltammetric curves at a rotating platinum disc electrode. It was found that $D_{\mathrm{Ag}(\mathrm{CN})^{-}}$at $298 \mathrm{~K}$ is practically independent of the $\mathrm{CMC}$ concentration; this result agrees with [11].

From mass transfer experiments at $298 \mathrm{~K}$, it follows that the $\log k / \log n$ curves at $i=2 \mathrm{kA} \mathrm{m}^{-2}$ and $v_{\mathrm{s}, \mathrm{o}}=0.2 \mathrm{~m} \mathrm{~s}^{-1}$ and at various contents of CMC are parallel. For the top $0.04 \mathrm{~m}$ of the working electrode it was found that in the current density range from 0.1 to $4 \mathrm{kA} \mathrm{m}^{-2}$, the $\log k_{\mathrm{u}, \mathrm{a}} / \log i_{\mathrm{H}}$ curve at $v_{\mathrm{s}, \mathrm{o}}=0.2 \mathrm{~m} \mathrm{~s}^{-1}$ and for a solution without addition of $\mathrm{CMC}$, is parallel to that for a solution with a con-

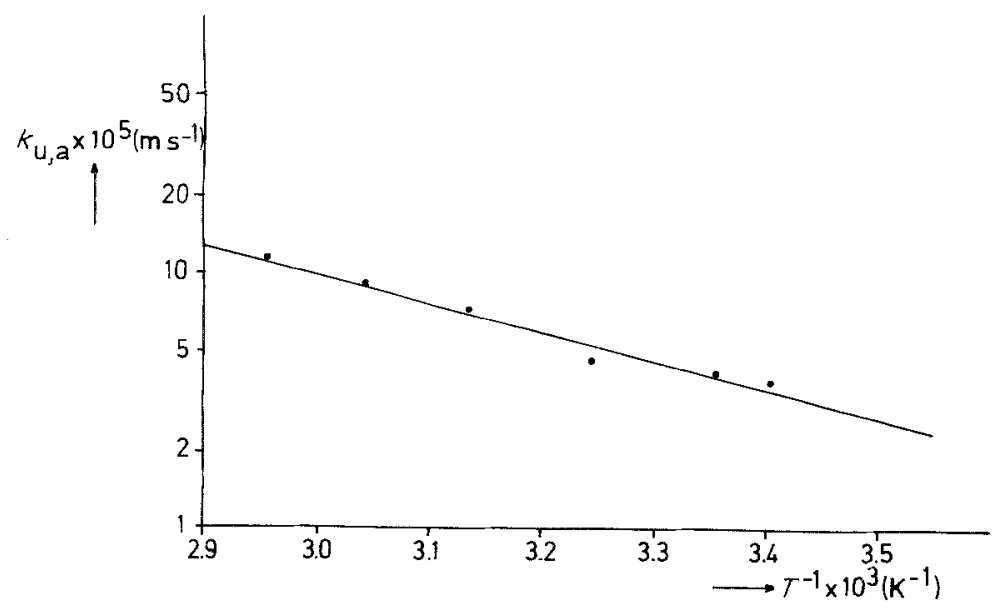

Fig. 13. Logarithm of the average mass transfer coefficient for the topmost $0.4 \mathrm{~m}$ of an electrode plotted vs the reverse of absolute temperature for a new segmented electrode at $i_{\mathrm{H}}=0.75 \mathrm{kA} \mathrm{m}^{-2}$ and a flow rate of solution on entrance of $0.1 \mathrm{~m} \mathrm{~s}^{-1}$. 


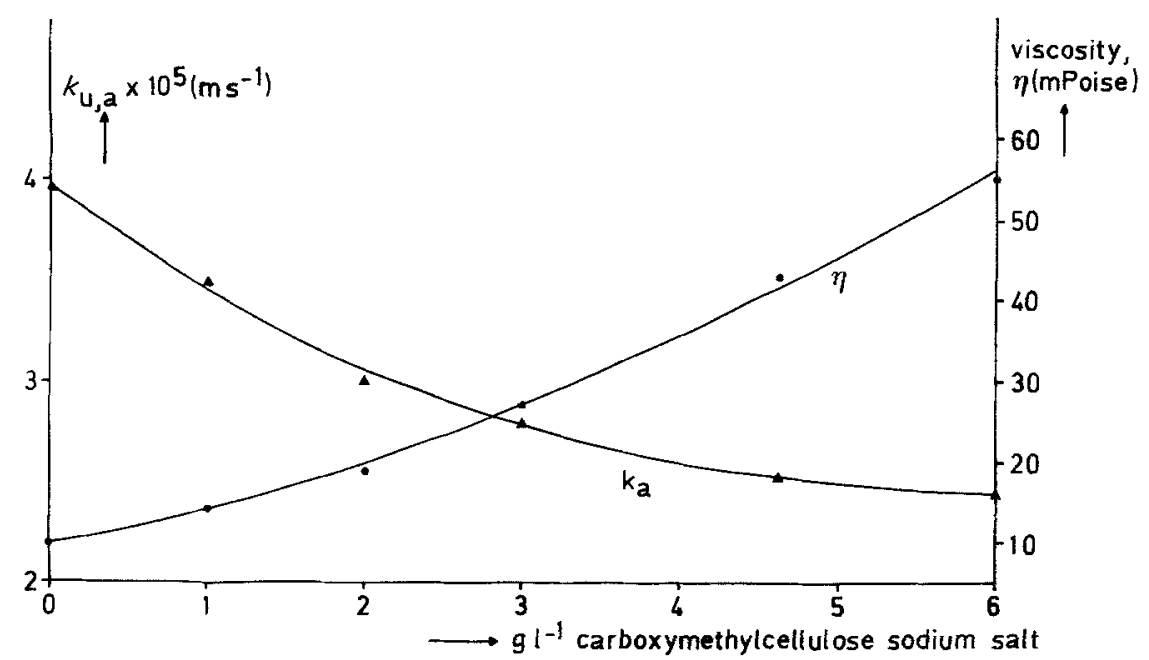

Fig. 14. Average mass transfer coefficient for the topmost $0.4 \mathrm{~m}$ of an aged electrode at $i_{\mathrm{H}}=1 \mathrm{kAm}^{-2}$ and a flow rate of solution on entrance of $0.2 \mathrm{~m} \mathrm{~s}^{-1}$ and viscosity of bubble-free solution plotted as a function of concentration of carboxymethylcellulose sodium salt.

centration of $60 \mathrm{~g} \mathrm{CMC} \mathrm{m}^{-3}$. For the topmost $0.4 \mathrm{~m}$ of the working electrode, the effect of the CMC concentration on the mass transfer coefficient $k_{\mathrm{u}, \mathrm{a}}$ at $i=2 \mathrm{kA} \mathrm{m}^{-2}$ and $v_{\mathrm{s}, \mathrm{o}}=0.2 \mathrm{~m} \mathrm{~s}^{-1}$ is given in Fig. 14 . The average mass transfer coefficient $k_{\mathrm{u}, \mathrm{f}, \mathrm{a}}$ at $v_{\mathrm{s}, \mathrm{o}}=0.2 \mathrm{~m} \mathrm{~s}^{-1}$ and in the absence of hydrogen evolution is $0.99 \times 10^{-5} \mathrm{~m} \mathrm{~s}^{-1}$ and $1.53 \times 10^{-5} \mathrm{~m} \mathrm{~s}^{-1}$, for solutions with 60 and $0 \mathrm{~g} \mathrm{CMC} \mathrm{m}^{-3}$, respectively. Figure 14 shows that $k_{\mathrm{u}, \mathrm{a}}$ declines sharply with increasing solution viscosity. The ratio $k_{\mathrm{u}, \mathrm{a}} / k_{\mathrm{u}, \mathrm{f,a}}$ does not depend on the $\mathrm{CMC}$ concentration. Consequently, the enhancement factor, $\beta$, is independent of the viscosity of solution.

\subsection{Mass transfer to non-gas-evolving segments of an electrode in a cell with gas evolution}

The mass transfer to non-gas-evolving segments was investigated when bubbles were formed on working electrode segments placed between these segments and the leading edge of the working electrode. During $\mathrm{Ag}$ deposition, segments 9 and 18 were polarized at $-1050 \mathrm{mV}$ and the other segments were polarized with a cathodic current adjusted by a variable resistance and four $12 \mathrm{~V}$ batteries. A series of experiments was carried out at a solution flow rate of $0.1 \mathrm{~m} \mathrm{~s}^{-1}$ and at various cathodic currents from 5 to $30 \mathrm{~A}$. Figure 15 shows $k_{\mathrm{n}}$ as a function of segment number, $n$, with $20 \mathrm{~A}$ galvanostatic polarization of all the segments, and of all the segments except segments 9 and 18. The mass transfer coefficients $k_{\mathrm{f}, 9}$ and $k_{\mathrm{f}, 18}$, in the absence of gas evolution and under the conditions of Fig. 15, are $0.89 \times 10^{-5}$ and $0.72 \times 10^{-5} \mathrm{~m} \mathrm{~s}^{-1}$, respectively. From these results and Fig. 15 it follows that mass transfer to a segment is enhanced by gas evolution on it. It has been found that the $\log k / \log i_{\mathrm{H}}$ curves are parallel for the segments 7-11 inclusive and 16-20 inclusive, where no hydrogen is formed on segments 9 and 18 .

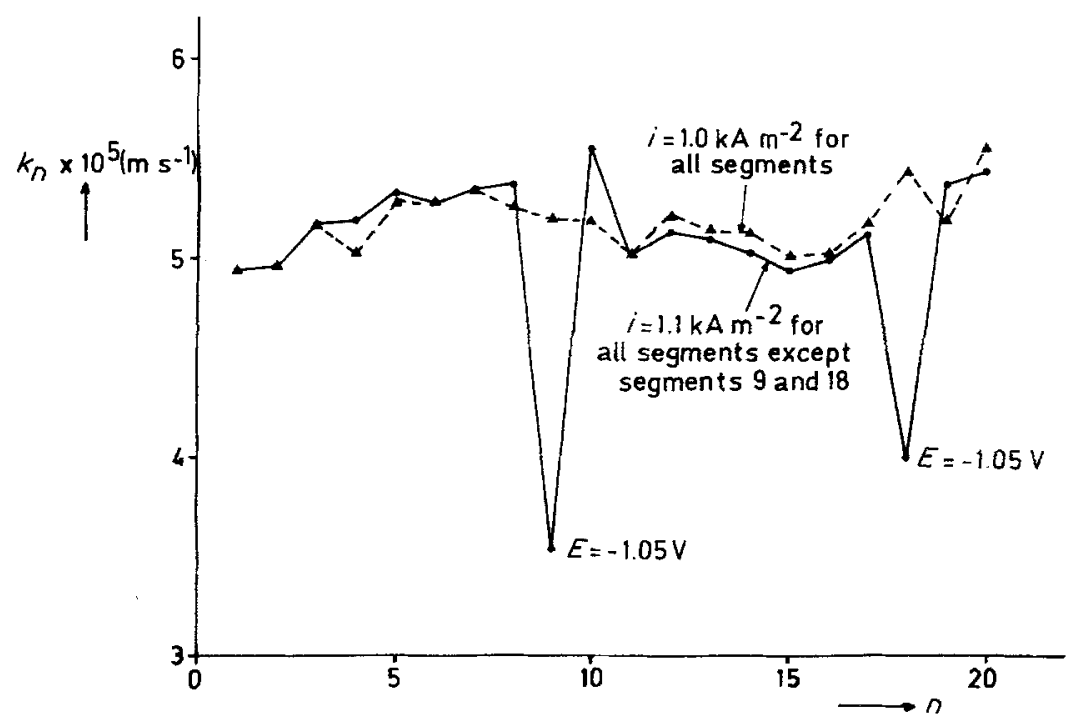

Fig. 15. Mass transfer coefficient for each segment for a new electrode of which all the segments are cathodically polarized with $1.0 \mathrm{kA} \mathrm{m}^{-2}$ and of which all the segments except segments 9 and 18 are cathodically polarized with $1.1 \mathrm{kA} \mathrm{m}^{-2}$. Segments 9 and 18 are polarized at a potential of $-1.05 \mathrm{~V}$ vs $\mathrm{Hg}-\mathrm{HgO}-1 \mathrm{M} \mathrm{KOH}$ reference electrode. The flow rate of solution on entrance $=0.1 \mathrm{~m} \mathrm{~s}^{-1}$. 


\section{Discussion}

From the results of Section 3.1, it follows that the $\mathrm{Ag}-\mathrm{Ag}^{+}$redox couple in an alkaline cyanide solution is very useful for determining mass transfer to hydrogen-evolving electrodes in alkaline solution. In contrast to the ferrocyanide-ferricyanide couple, this redox couple in particular is very suitable for investigating the dependence of the mass transfer coefficient of the indicator ion on the electrode height.

Only a small quantity of $\mathrm{Ag}$ is deposited on one segment of the working electrode during cathodic polarization. The maximal quantity of $\mathrm{Ag}$ corresponds to a layer thickness of about $0.7 \mu \mathrm{m}$. Since the least thickness of the Nernst diffusion layer for $\mathrm{Ag}(\mathrm{CN})_{2}^{-}$ions is about $5 \mu \mathrm{m}$, it is likely that the roughness of the Ag layer deposited does not significantly affect the mass transfer to the hydrogen-evolving electrode. This conclusion is supported by the absence of any effect of the time of cathodic polarization.

The experimental results can be divided into two groups, namely one for the bright platinum electrode and the other for the dull platinum electrode. It is well known that the nature of the electrode surface affects the mass transfer to a gas-evolving electrode and the size of the bubbles evolved [5]. In spite of deposition of a silver layer during cathodic polarization, it may be concluded that the behaviour of bubbles evolved in the Ag layer is still affected by the platinum substratum of the working electrode. Only the magnitude of the mass transfer coefficient, $k$, clearly differs between the new and the aged electrode. The slope of the $\log k_{\mathrm{u}, \mathrm{a}} / \log i_{\mathrm{H}}$ curve (Fig. 10) and that of the $\log k_{\mathrm{u}, \mathrm{a}} / T^{-1}$ curve (Section 3.4.2.2) are not affected by the nature of the electrode surface. Moreover, the ratio between $k_{\mathrm{u}, \mathrm{a}}$ for the new electrode and that for the aged electrode is 1.50 and is independent of the flow rate of solution, $v_{\mathrm{s}, \mathrm{o}}$ (Fig. 12). From these results and from the correlation for the mass transfer coefficient, $k_{\mathrm{u}, \mathrm{a}}$, it follows that for the topmost $0.40 \mathrm{~m}$ of the working electrode, the general correlation

$$
k_{\mathrm{u}}=a_{1}\left[1.3+1.7 v_{\mathrm{s}, 0}^{0.71}\right] 10^{\left[-5+0.24 i_{\mathrm{H}}^{0.38}\right]} \mathrm{m} \mathrm{s}^{-1}
$$

where $v_{\mathrm{s}, \mathrm{o}}$ and $i_{\mathrm{H}}$ are given in $\mathrm{m} \mathrm{s}^{-1}$ and $\mathrm{kA} \mathrm{m}^{-2}$, respectively, and $a_{1}$ is a factor depending on the nature of the electrode surface. For the aged electrode $a_{1}=1.0$ and for the new electrode $a_{1}=1.5$.

What is remarkable, on the one hand, is the strong enhancement of the mass transfer coefficient for a segment caused by bubbles passing this segment (Fig. 15) and, on the other hand, the decrease in mass transfer coefficient at $n<5$ and the practically constant value with increasing $n$ or height in the cell, where the average gas void fraction increases with increasing height in the cell (Fig. 9).

It is well known that, in the space between a gasevolving electrode and a membrane, the bubbles are not uniformly distributed across the cross-section. The gas void fraction declines sharply with increasing distance from the electrode surface [12]. It is likely that only the bubbles rising within the mass transfer boundary layer at an electrode will enhance mass transfer to this electrode significantly. These rising bubbles cause mixing within the boundary layer at the electrode. A model describing the contribution of these rising bubbles to the enhancement of mass transfer is presented in [13]. This type of enhancement will be referred to as the 'friction mechanism' in the present paper. A similar type of mechanism for mass transfer occurs in electrolysers with forced flow of a gas-liquid mixture [14] and with gas sparging [15]. In these cases, based on the results of Rietema and Ottengraf [16], it can be concluded that the gas void fraction is least on the electrode surface and that it increases with increasing distance from the electrode surface up to a constant level. Rietema et al. have described a bubble street, created by air bubbles dispersed homogeneously at the bottom of a cylindrical column. It is likely that the effectiveness of the friction mechanism depends strongly on the distribution of the gas void fraction in the cell and, in particular, on the gas void fraction close to the electrode surface. The results of Figs 9 and 15 can be brought together by assuming that the gas void fraction or the bubble density close to the non-gas-evolving segments as well as to the gas-evolving segments, are much higher than those in the bulk solution. This means that the bubble density in the bulk solution has practically no effect on the mass transfer of indicator ions to the segments of the working electrode under the conditions of this paper. Evidently, the bubble density at a gas-evolving segment is higher than that at a non-gas-evolving segment. Looking at Fig. 15, it follows that the bubble evolution on a segment significantly enhances the mass transfer coefficient, $k_{n}$, to this same segment. The enhancement of the mass transfer to a gas-evolving segment is caused by bubbles formed and sliding over it, by bubbles formed and detached from it and rising close to the segment surface, as well as by bubbles detached from lower segments rising close to the surface of this segment. Only the latter factor will enhance mass transfer to a non-gas-evolving segment. It is likely the rising bubble trajectories from lower segments move still further away from the electrode surface owing to on-site bubble evolution. This means that the contribution of bubbles formed on lower segments to mass transfer to a higher segment is much less than that which follows from Fig. 15, so that it can be neglected. Based on the behaviour of a hydrogenevolving electrode in alkaline solution it follows that mass transfer of indicator ions to a segment of the working electrode can be described by the model of an ensemble of detached sliding and rising single bubbles where the contribution of rising bubbles formed on electrode up-flow segments is neglected [13].

It can be shown that the theoretical relation for the mass transfer coefficient and the enhancement factor agree qualitatively with the experimental results. A quantitative verification of the models in the literature [13] is impossible with the results of the present paper. 


\section{References}

[1] M. G. Fouad and G. H. Sedahmed, Electrochim. Acta 17 (1972) 665.

[2] L. J. J. Janssen, J. Appl. Electrochem. 17 (1987) 1177.

[3] L. J. J. Janssen, C. W. M. P. Sillen, E. Barendrecht and S. J. D. van Stralen, Electrochim. Acta 29 (1984) 633.

[4] J. M. Chin Kwie Joe and L. J. J. Janssen, will be published.

[5] L. J. J. Janssen and E. Barendrecht, "Dechema-Monographien Band 98, Verlag Chemie (1985) p. 463.

[6] R. C. Bowers and J. M. Kolthoff, J. Am. Chem. Soc. 81 (1959) 1836.

[7] A. J. Bard, 'Encyclopedia of Electrochemistry of the Elements', Marcel Dekker, New York (1978) Vol. 8.

[8] R. C. Weast and S. M. Selly, 'Handbook of Chemistry and Physics', The Chemical Rubber Co., Ohio, 48th edition (1967) B-284.
[9] J. E. Funk and J. F. Thorpe, J. Electrochem. Soc. 116 (1969) 48.

[10] J. H. G. Verbunt, L. J. J. Janssen and S. J. D. van Stralen, unpublished work.

[11] O. N. Cavatorta and U. Böhm, J. Appl. Electrochem. 17 (1987) 340.

[12] B. E. Bongenaar-Schlenter, L. J. J. Janssen, S. J. D. van Stralen and E. Barendrecht, J. Appl. Electrochem. 15 (1985) 537.

[13] L. J. J. Janssen, Electrochim. Acta 34 (1989) 161.

[14] D. J. Economou and R. C. Alkire, J. Electrochem. Soc. 132 (1985) 601 .

[15] L. Sigrist, O. Dossenbach and N. Ibl, Int. J. Heat Mass Transfer 22 (1979) 1393.

[16] K. Rietema and S. P. P. Ottengraf, Trans. Instr. Chem. Eng. 48 (1970) T54. 